\title{
Familiar Birds of the Alaska Highway Country
}

By Eva Mudrman, Whitehorse, Y.T.

THE GENTLE CHINOOK had breathed softly over the land a deceivingly spring-like atmosphere permeated the Peace country. Walking down the highway, the silence was so intense you could hear it. On either side stretched miles of gloomy spruce and jackpine stands, occasionally broken by burned over areas, strewn with masses of deadfall, now appearing darkly through the melting winter snows. A couple of Northern Ravens, flying low, broke the stillness with their raucous cries; watching them disappear into the woods, I suddenly became aware of many clear chirping birdcalls coming from a grove across the way.
On investigation, I saw what looked like flashes of scarlet in motion against the green boughs. So many beautiful little red birds, either hanging from the boughs or darting about, and so busy were they digging out the cone seeds with their scissor-like little bills that they didn't know I existed. I had seen my first flock of American Crossbills; there must have been at least thirty but they were too hungry and active to be counted. Every year their relatives, the White-winged Cross-bills, visited the Peace country and also the Yukon. However, the Red American Cross-bills had been rarely seen here in the vicinity of Dawson Creek, B.C.

\section{Some Birds Found on the Northern Canadian End of the Alaska Highway}

\section{WINTER BIRDS}

$I^{\mathrm{N}}$ LATE NOVEMBER the Snow Buntings arrive, and it is often mid-April before they proceed to their Arctic nesting regions. The Canada'Jay or "Whiskey Jack", as he is called here, is a saucy camp pet. Other winter favorites are the Black-capped and Brown-capped Chickadees, also the little Slatecolored-Juncoes. One winter when the temperature dropped to 81 degrees below zero many of these licte birds were found to have succumbed to the cold. The Raven and Magpie, in search of food, are also familiar winter sights at camp, while from the woods resound the clear whistling notes of the cruel Northern Shrike.

On their daily trips to clear the highway and wage their constant battle against the encroaching glaciers, the maintenance men of camp Mile 1156 saw many birds, such as the Snow-white Ptarmigans, several Hawks, large Grey Eagles and the Little Downy and the Northern Hairy Woodpeckers. The Baldheaded Eagle grows so huge there and gets very bold. A small husky puppy, which always followed its master on the underblade, was pick- ed up by one of these eagles, one day. The man, hearing pitiful cries, rushed out in time to see the bird drop the dog, but its back was injured. Flocks of little Red-polls are seen here in March and November. In late December and in January the Alaskan Grosbeaks arrive.

\section{SPRING AND SUMMER BIRDS}

THIS YEAR (1951), Spring came 1 late to the Yukon. The first mountain Bluebird was seen about April 14 and it was May 1 before we heard the Robin's cheery carol again. The ice on the Yukon River went out on April 29, but the ice on the lakes will remain for about a month later. Thus it is that the Gulls are now flying above the rushing, green river waters. How beautiful they look as they circle and wheel in the air with the sun glacing off their snowy wings. Some Gulls noted here are the Arctic Tern, Bonaparte's Gull and the Herring Gull. Sandpipers, Plovers and Killdeers are also seen along the beaches.

In Spring and Fall flocks of Canadian Geese, Snow Geese and Whistling Swans fly over in their graceful formations. Some Ducks seen were 